\title{
A SURVEY OF THE TEACHING OF STATISTICAL LITERACY, REASONING AND THINKING: TEACHERS' CLASSROOM PRACTICE IN MEXICAN HIGH SCHOOL EDUCATION
}

\author{
ANA LUISA GÓMEZ-BLANCARTE \\ Instituto Politécnico Nacional \\ algomezb@ipn.mx \\ REYNALDO ROCHA CHÁVEZ \\ Instituto Politécnico Nacional \\ rrochac@ipn.mx \\ ROSA DANIELA CHÁVEZ AGUILAR \\ Instituto Politécnico Nacional \\ daniela.chavez@gmail.com
}

\begin{abstract}
This paper presents partial results of a one-year project funded by a grant from Mexico's National Science and Technology Council and the National Institute for the Evaluation of Education that was designed to characterize the teaching of statistics in Mexican high school education. Work was organized in two 6-month phases. The first stage involved documentary research that consisted of analyzing the study programs of statistics courses used at 12 high school-level educational systems. The second used the field research technique to design and administer a survey called "Teaching Statistical Literacy, Reasoning and Thinking" (TSLRT), that was answered by 754 high school statistics teachers at those 12 educational systems. Both phases were based on the theoretical ideas of statistical literacy, reasoning and thinking, and were conducted with the aim of constructing a reference framework to analyze the study programs (phase one) and design the items included in the TSLRT survey (phase two). Here, we report results from the survey applied, which was comprised of 18 items on sociodemographic variables and 65 Likert scale items that measured the degree to which teachers' classroom practice focused on elements of statistical literacy, reasoning and thinking, or shared elements. Confirmatory factor analysis was applied to the responses to the 65 Likert scale items. Results indicate that the responses fit a one-dimensional model. Finally, we discuss the pedagogical and theoretical implications of the TSLRT survey results.
\end{abstract}

Keywords: Statistics education research; Statistics teaching; Statistical literacy; Statistical reasoning; Statistical thinking; Statistics teaching in Mexico

\section{INTRODUCTION}

Internationally, researchers in the field of statistics teaching have participated in evaluating the status of statistics in school curricula and the way in which teachers perceive statistics courses. The results of this research are fundamental because of the suggestions or recommendations they offer to improve statistics teaching (e.g., American Statistics Association, 2016; Franklin et al., 2005). The status of statistics teaching in schools continues to be a basic topic for research in this field. The book by Batanero et al. (2011) presents studies by researchers in the United States, Brazil, Uganda and South Africa that provide examples of how statistics teaching is performed in the school curricula of their countries (e.g., Campos et al., 2011; Newton et al., 2011; Opolot-Okurut \& Eluk, 2011; Wessels, 2011). That research provides information that allows us to discern the challenges facing the teaching of statistics and probability in order to, for example, implement guidelines for teaching these disciplines that are established in curricula, but surpass curricular expectations. Some challenges to the teaching of statistics in those countries are: 
- In Brazil: 1) initial and ongoing teacher training; 2) books that contain didactic errors and present the content in a fragmented manner; 3) scarcity of didactic materials; 4) research results are not made available in schools; and 5) lack of free software adequate for each educational level (Campos et al., 2011).

- In Uganda: 1) the teaching process centers on the teacher and is oriented towards evaluation;2) the review of students' evaluations is rarely promoted; and 3) the textbook is the first resource used for the problems seen in class (Opolot-Okurut \& Eluk, 2011). Wessels (2011) presents a more general vision of the condition and contents of statistics in South Africa in the curricula for elementary and secondary schools, where one problem identified is that mathematics teachers need support for teaching statistics curricula.

- In the US: 1) reports of a greater emphasis on having students analyze data and interpret results than on formulating questions and gathering data; 2) only $2 \%$ of 41 curricular documents include the expectation that students will plan and develop a statistical process; and 3) only $28 \%$ of 41 documents promote the development of statistical reasoning (Newton et al., 2011). Those authors stress that it is important for teachers to see curricular expectations as minimum requirements, so they can include developing the process of doing statistical research and statistical reasoning in their teaching.

The research listed exemplifies the work required to generate consciousness about the status of statistics teaching that would lead to implementing specific actions designed to improve teaching and learning in this discipline. Researchers in Mexico have participated only scantly in analyses of the status of statistics and probability in national education. For example, Sánchez' work (2009) presented a review of the 2006 Programa de Estudio de Matemáticas (Mathematics Study Program) for middle school education regarding the sub-topic of "notions of probability". On the one hand, a comparative analysis of "knowledge and abilities" was introduced that compared this program to curricula from other countries, such as Australia, the United States, the United Kingdom and Spain, as well as to Mexico's own 1993 curriculum. On the other hand, the program's "didactic orientations" were compared to the elements of a Probability Literacy. One of Sánchez' results was the absence of the study of frequentist probability in the programs analyzed, which "hinders the emergence of the "great ideas' of randomness, variation and predictability/uncertainty" (p. 73), which are components of knowledge in a Probability Literacy. Sánchez' research influenced the incorporation of content related to the notion of frequentism in the 2011 Programa de Estudio de Matemáticas (see Secretaría de Educación Pública [SEP], 2011).

\subsection{BACKGROUND TO THE STUDY}

In Mexico, interest in statistics teaching emerged due to this field's usefulness for development in the country. According to Casanova (2005), the first statistics courses began in higher education (tertiary level) and centered on studying the data from demographic and commercial censuses. Currently, the study of statistics is included among the math topics taught starting in Basic Education (6-15-year-olds). In the case of the higher middle education (EMS for its acronym in Spanish), or high school (15-18-year-olds), statistics is studied in the $4^{\text {th }}, 5^{\text {th }}$, or $6^{\text {th }}$ semester of a six-semester program, depending on the school educational system chosen; that is, statistics subjects tend to be studied at the end of high school. Some school educational systems offer the subject of statistics as an optional course instead of an obligatory one. The various educational systems may establish their own study programs for their schools. This means that both the statistical content and emphasis of its study differ from one system to another.

The diversity of EMS options was designed with the intention of meeting the different needs of youths (in light of social and economic differences), but in 2008, a process of integrating these educational options through a program called the Reforma Integral de la Educación Media Superior (Integral Reform of Higher Middle Education, RIEMS) began. RIEMS stipulates creating a Marco Curricular Común (Common Curricular Framework, MCC) for the development of disciplinary skills that EMS options must apply. In the case of statistics, the MCC contemplates studying probability and statistics in a disciplinary axis called "From information management to stochastic thought" (SEP, 
2017). In this way, the different EMS options should coincide in studying central contents like those shown in Table 1.

Table 1. Central content for the disciplinary axis "From information management to stochastic thought” (SEP, 2017, pp. 238-239)

\begin{tabular}{|c|c|c|}
\hline Central content & Expected learnings & Expected products \\
\hline 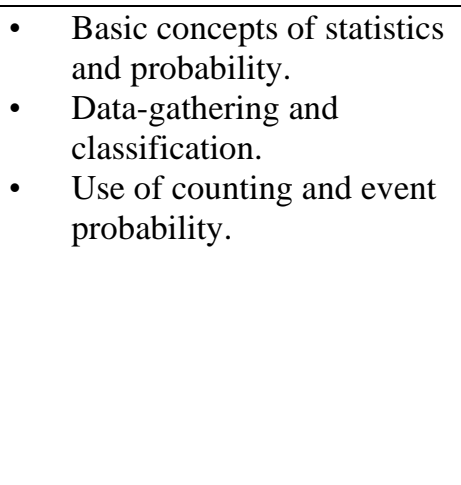 & $\begin{array}{l}\text { - Use of proper language for } \\
\text { situations that require study } \\
\text { using elements of statistics and } \\
\text { probability. } \\
\text { Use of counting or grouping } \\
\text { techniques when determining } \\
\text { probabilities. } \\
\text { Organizing information as part } \\
\text { of statistics for the study of } \\
\text { probability. } \\
\text { Studying the complement that } \\
\text { statistics offers for probability. }\end{array}$ & $\begin{array}{l}\text { Calculate the average } \\
\text { from a set of data. }\end{array}$ \\
\hline $\begin{array}{l}\text { Information management } \\
\text { in everyday situations. }\end{array}$ & 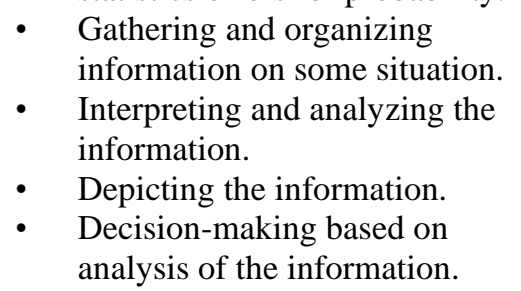 & $\begin{array}{l}\text { Make different types } \\
\text { of graphs and provide } \\
\text { opinions derived from } \\
\text { them. }\end{array}$ \\
\hline $\begin{array}{l}\text { - Managing central tendency } \\
\text { measures. } \\
\text { Managing and } \\
\text { understanding dispersion } \\
\text { measures. }\end{array}$ & $\begin{array}{l}\text { Calculating central tendency } \\
\text { measures, dispersion } \\
\text { measures, form measures and } \\
\text { correlation measures. } \\
\text { Interpreting central tendency } \\
\text { measures from the analysis of } \\
\text { statistical graphs, as well as } \\
\text { their variability and } \\
\text { representation of the } \\
\text { contextual situation. } \\
\text { Decision-making based on } \\
\text { central tendency measures and } \\
\text { their depiction according to a } \\
\text { set of data. }\end{array}$ & $\begin{array}{l}\text { Argue what central } \\
\text { tendency and } \\
\text { dispersion measures } \\
\text { are. } \\
\text { - } \quad \text { Provide examples of } \\
\text { said measures. } \\
\text { Make quartiles based } \\
\text { on the data provided. }\end{array}$ \\
\hline
\end{tabular}

For the three central contents of this disciplinary axis, the expected learning implies such abilities as gathering, organizing, ordering, interpreting, depicting and analyzing information using statistical models like central tendency and dispersion measures, and then making decisions according to the analysis of these measures. While these abilities could demand statistical ideas at a more conceptual than procedural level, when the expected products are observed, this exigency is reduced to more procedural knowledge. In other words, it requires procedures such as "calculating", "making", "arguing what a central tendency and dispersion measures are", and "making quartiles based on the data provided". However, it is important to clarify that each EMS option is free to expand and deepen these contents according to their different training objectives.

The fact that the curricula of Basic Education and EMS in Mexico contemplate the study of statistics is an important advance, but it does not suffice because, according to Batanero (2001), "In reality, there are still too few teachers that include this topic and, in other cases, it is taught very briefly or in an excessively formalized manner" (p. 6). Furthermore, the curricular programming of statistical topics, which are normally seen at the end of a unit or in the final semesters, as well as the knowledge that the teachers have about this discipline, have led many teachers to encourage a more procedural and fragmented learning than a conceptual and holistic approach to statistics (Gómez-Blancarte, 2015). 


\subsection{AIM OF THE STUDY}

Given the need to generate consciousness about the status of statistics teaching in Mexico, a oneyear research project was conducted with funding from Mexico's Fondo Mixto del Consejo Nacional de Ciencia y Tecnología and the Instituto Nacional para la Evaluación Educativa (CONACYT-INEE). The objective of the project was to characterize statistics teaching at EMS level in Mexico. This article presents some results from the project regarding, primarily, the design and application of a questionnaire with sociodemographic, socioeconomic and educational sections, and statistical content items. The results shown in this article reflect the responses that correspond to the content items, with the goal of measuring the focus (statistical literacy, reasoning or thinking) of the statistics teaching that EMS teachers promote during their statistics classes. With Garfield and Franklin (2011), we consider it important and necessary to determine the kind of statistics teaching that teachers offer in their classrooms in order to generate specific actions that will make it possible to improve the teaching of this discipline. In summary, this article has a dual purpose: 1) to subject the research instrument developed to discussion; and 2) to ascertain the focus that EMS teachers promote in their statistics teaching.

\section{THEORETICAL IDEAS}

The community of researchers on statistics teaching proposes that the teaching of this discipline should revolve around three approaches: 1) statistical literacy (SL); 2) statistical reasoning (SR); and 3) statistical thinking (ST) (e.g., Ben-Zvi \& Garfield, 2004; Garfield \& Ben-Zvi, 2008). In fact, there is a community interested in studying the development of these approaches in students called International Statistical Reasoning, Thinking, and Literacy Research Forums [SRTL].

The theory of SL, SR and ST-also known as the three results of the learning desired by students immersed in statistics education (delMas, 2002; Ben-Zvi \& Garfield, 2004; Garfield \& Ben-Zvi, 2008; Garfield, 2011; Ziegler, 2014) - proposes a general view to differentiate among the kinds of statistics teaching that teachers offer in their classrooms. According to delMas (2002), the three approaches (SL, SR and ST) "represent our intention, as teachers, to develop in our students' statistical literacy, reasoning and thinking in the discipline of statistics" (p. 1). In this sense, the statistics teaching of any particular teacher can have, implicitly, traits of one of these three approaches, even though she/he may not be aware of it.

The literature suggests that these approaches can be independent, but with overlapping characteristics (e.g., delMas, 2002; Garfield \& Ben-Zvi, 2004) (see Figure 1a) and, perhaps, a certain hierarchy. delMas (2002), for example, pointed out that one way to perceive these three approaches is that SR and ST are sub-goals of SL; that is, the contents of SR and ST have a certain level of overlap, but are not independent of the contents of SL (see Figure 1b). delMas added that, depending on the educational level, as in the case of advanced statistics course, ST can be considered to have the greatest hierarchy, but that its bases are in SR and ST. An example of this hierarchy is shown in GómezBlancarte and Santana (2018).

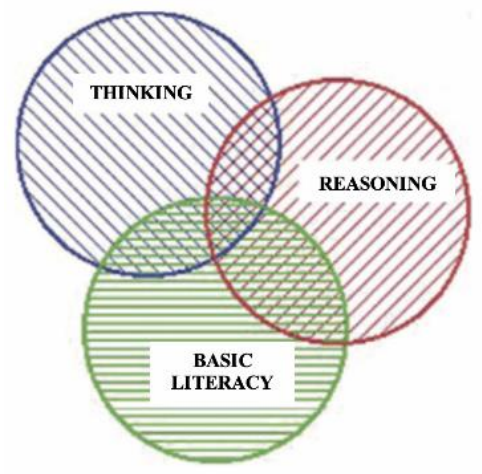

(a)

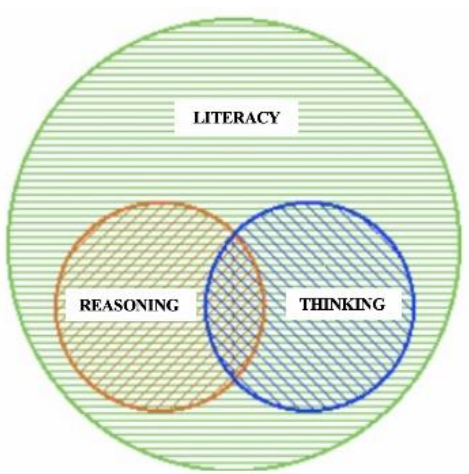

(b)

Figure 1. Approaches to statistics teaching (from delMas, 2002) 
Using the definitions and theoretical distinctions related to SL, SR and ST, we built a framework of indicators that allows us to identify the characteristics of each approach. Due to space limitations, we cannot show the whole set of indicators (see Chávez, 2020, for a more detailed account of the indicators); instead, we present the main theoretical ideas that were considered as we constructed this set of indicators for each focus.

\subsection{STATISTICAL LITERACY}

SL is characterized by its focus on the learning of statistics through the acquisition of the basic skills used to understand statistical information that appears in different media (e.g., newspapers, magazines, TV shows, websites, social media, etc.). It includes the abilities that all citizens need to interpret, critically evaluate, and communicate statistical information and its messages ( $\mathrm{Gal}, 2002)$. To build the set of indicators for this approach, we reviewed theoretical ideas, primarily, from Gal (2002, 2004), who proposed understanding SL as a set of elements of both knowledge and disposition (see Figure 2). In our case, we organized the indicators in terms of the five elements of knowledge-Literacy skills, Statistical knowledge, Mathematical knowledge, Context knowledge, and Critical questions - but did not take into account, elements related to disposition.

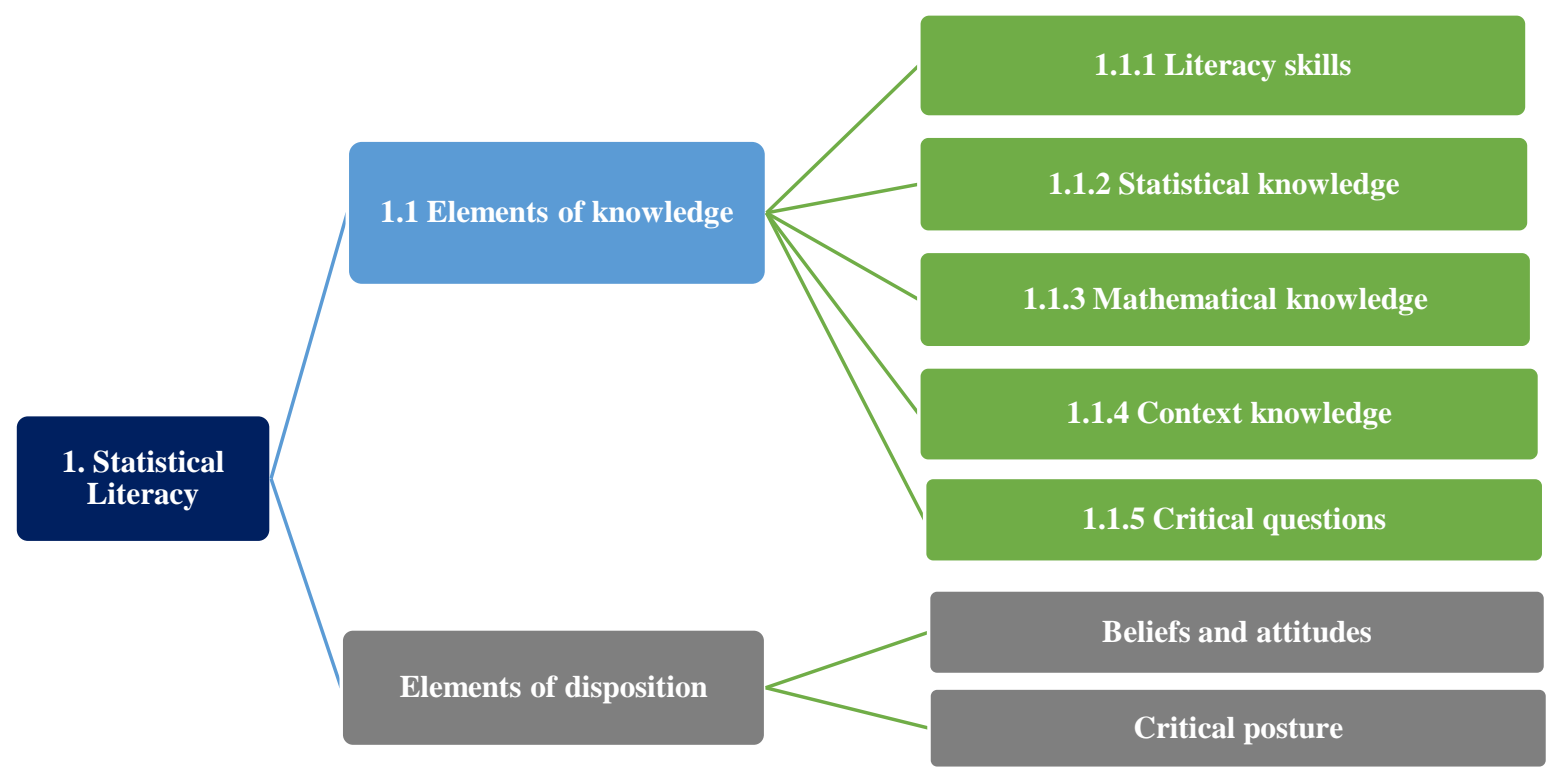

Figure 2. Elements of Statistical Literacy based on Gal's model (2002)

\subsection{STATISTICAL REASONING}

According to Ben-Zvi and Garfield (2004), SR focuses on developing the central ideas of statistics instead of presenting a set of tools and procedures. In light of this, we organized our indicators for measuring SR around "central statistical ideas", including data, distributions, variability, central measures, statistical models, randomness, sampling, co-variation and inference (Ben-Zvi \& Garfield, 2004; Garfield \& Ben-Zvi, 2008; Burrill \& Biehler, 2011). For each idea, we consulted important aspects to improve understanding and considered that SR can be observed as students become capable of justifying statistical processes and interpreting their results (Garfield, 2002; delMas, 2004). Another indicator of SR occurs when teachers promote a teaching environment designed to develop in students a profound, significant understanding of statistics and the use of evaluations to check what they know and monitor the development of their learning (Garfield \& Ben-Zvi, 2008). Figure 3 shows a representation of the theoretical ideas taken into account for the indicators of SR. 


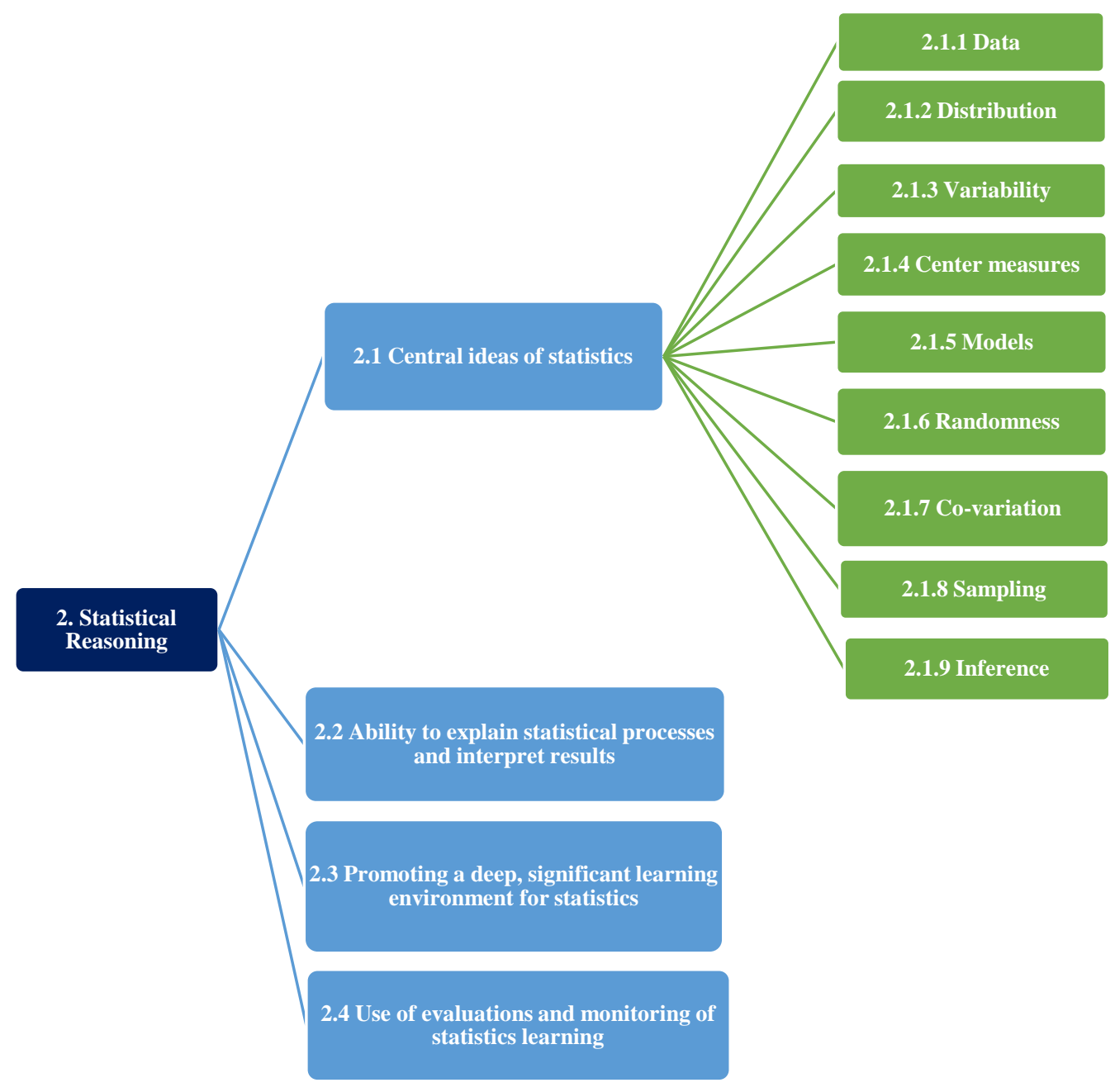

Figure 3. Elements of Statistical Reasoning.

\subsection{STATISTICAL THINKING}

The development of ST is related to a holistic understanding of statistical concepts and processes. It includes knowing the "how-and-why" behind the use of each method of data analysis and understanding the "why-and-how" of conducting statistical research (Ben-Zvi \& Garfield, 2004). This last factor suggests the ability to propose questions, collect data and select an adequate analysis based on the necessary assumptions of the data and problem. This entails the ability to understand and use the context of the problem to ensure that the conclusions integrate the statistics with that context (Wild \& Pfannkuch, 1999; Chance, 2002).

Statistical thinking can be understood as the interaction between the set of elements that make up the four-dimensional model proposed by Wild and Pfannkuch (1999); that is, an investigative cycle (dimension 1), fundamental types of statistical thinking (dimension 2), an interrogative cycle (dimension 3), and dispositions (dimension 4). The operation of these dimensions works in a nonhierarchical, non-linear fashion, such that various elements from the different dimensions can coincide while solving a statistical problem. For the purposes of this project, we considered the elements of the first two dimensions to determine the indicators of ST (see Figure 4), which are related to how an investigator would operate during the solving of a statistical problem (investigative cycle), and the cognitive ability that each phase of the solution process demands (fundamental types of statistical thinking). 


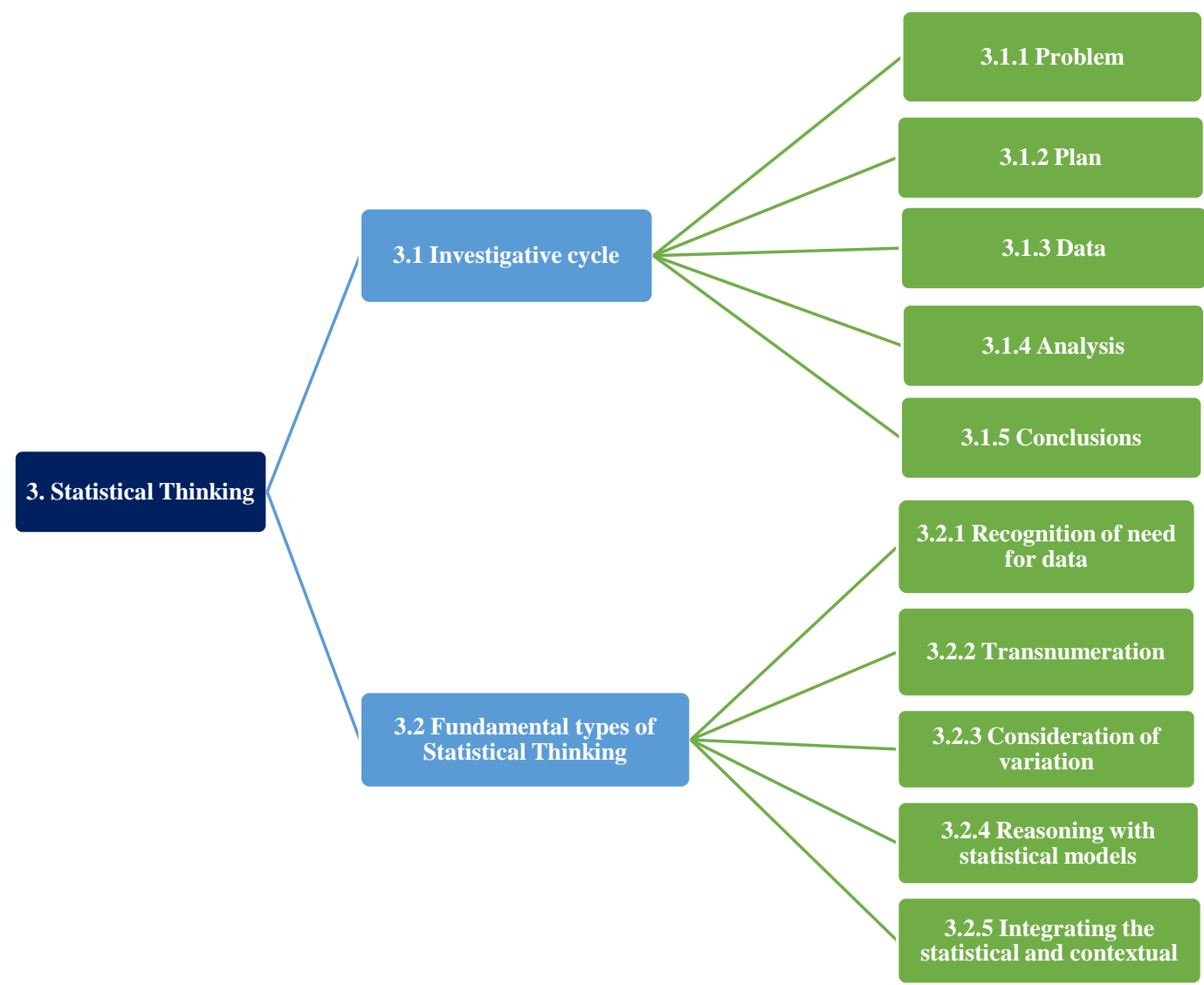

Figure 4. Elements of statistical thinking (adapted from Wild \& Pfannkuch, 1999)

\section{METHOD}

\subsection{PARTICIPANTS}

The frame of reference for selecting the sample of EMS schools was the list of educational systems regulated by the Comisión Metropolitana de Instituciones Públicas de Educación Media Superior (COMIPEMS), which covered Mexico City and 22 cities in the State of Mexico. Twelve educational systems with a total of 422 schools were chosen. Some issues arose during the process of obtaining the official permits necessary to interview teachers and during our visits to schools. For example, some schools did not have a main teacher for this subject, schools that did not offer statistics courses, and schools with only one teacher. These issues impeded obtaining the expected sample ( 844 teachers, 2 from each school). In the end, it was only possible to interview 754 teachers from 413 schools (see Table 2).

These 12 educational systems operated in the domain of public education. Educational systems 1-9 (see Table 2) are the most representative types of EMS systems at the national level. Educational system 10 operated exclusively in the State of Mexico, and schools with educational systems 11 and 12 were in Mexico City. These last two cases are EMS schools that pertained to the Instituto Politécnico Nacional (no. 11) and the Universidad Nacional Autónoma de México (no. 12). 
Table 2. Distribution of the teachers interviewed by educational system

\begin{tabular}{llcc}
\hline No. & Educational system & $\begin{array}{c}\text { No. of schools } \\
\text { visited }\end{array}$ & $\begin{array}{c}\text { No. of teachers } \\
\text { interviewed }\end{array}$ \\
\hline 1 & COLBACH & 20 & 40 \\
2 & CONALEP CDMX & 27 & 54 \\
3 & DGB & 2 & 4 \\
4 & UEMSTAyCM & 2 & 4 \\
5 & UEMSTIS & 51 & 102 \\
6 & CBT & 44 & 78 \\
7 & COBAEM & 20 & 32 \\
8 & CONALEP & 30 & 60 \\
& EDOMEX & & \\
9 & CECyTEM & 26 & 46 \\
10 & EPOEM & 161 & 277 \\
11 & IPN & 16 & 31 \\
12 & UNAM & 14 & 26 \\
\hline & Total & 413 & 754 \\
\hline
\end{tabular}

The objective was to select, randomly, two teachers from each school who had to satisfy one of the following two inclusion criteria: either currently be teaching statistics courses or having two years of experience in teaching statistics. However, the educational authorities at the schools decided to assign the teachers we could interview, as long as they fulfilled the aforementioned characteristics. That selection process was based on the individual teacher's willingness to be interviewed. To motivate teachers to participate, the project leader (Author 1) drafted a sensitization letter that informed them of the purpose of the interviews, emphasizing the importance of their participation for fulfilling the project's objectives.

\subsection{THE RESEARCH INSTRUMENT}

As explained above, the design of the questionnaire was based on theoretical ideas related to SL, SR and ST. The questionnaire had 83 questions: 18 on sociodemographic, socioeconomic and educational variables, and 65 content items using a Likert-type scale to measure the level at which the teachers encouraged elements of SL, SR and ST in their classrooms. These 65 items were divided into items related to SL, SR, ST and the Common Nucleus $(\mathrm{CN})$. The latter measured, from our perspective, elements shared by the three approaches.

The questionnaire was a collaborative effort that involved the members of the project (the authors, 2 researchers and 1 post-graduate student). A set of questions was proposed for each approach according to the indicators planned previously. At the outset, a total of 221 items were proposed, distributed as follows: 114 for SL, 65 for SR and 42 for ST. Later, a filtering process was performed to select the questions we considered most representative of each approach. First, we identified items that seemed to be repeated in each approach, then three members of the project checked individually which of those questions would be most representative of each approach. This meant triangulating the information. Once all the members had selected their items, we came together to determine which ones matched, and they were chosen. In addition, we identified items that we considered relevant to the CN. This cleansing process was conducted twice, with the result that an instrument with a total of 69 questions was used in a pilot study.

Validation of the instrument. The instrument was validated by applying it to a sample model of 86 EMS teachers who participated voluntarily (pilot study). None of them were included in the final sample. Statistical validation consisted in calculating the discrimination index of the items, the itemtotal-corrected correlation, the reliability coefficient if one item was eliminated, and the instrument's global reliability $(\alpha=0.99)$. An exploratory factorial analysis was carried out by calculating the factorial charges and the communality of each question. This generated a unidimensional model that explained $69.6 \%$ of total variance with factorial charges of $0.739-0.896$, communalities of $0.546-0.804$, 
and a KMO fit index $=0.9$, which proved to be statistically significant $(p<0.001)$. Based on this validation, 4 items from the pilot version were eliminated from the final instrument, so the final research questionnaire had a total of 65 items, distributed as shown in Table 3.

Table 3. Distribution of the content items on the research instrument.

\begin{tabular}{|c|c|c|}
\hline Approaches & No. of items & Total \\
\hline Literacy & $\begin{array}{l}\text { 19i, 19s, 19v, 19w, 19y, 19z, } \\
\text { 19ae, 19af, 19ak, 19am, 19an, } \\
\text { 19as, 19ax, 19bb, 19bd, 19bf, } \\
\text { 19bk }\end{array}$ & 17 \\
\hline Reasoning & $\begin{array}{l}\text { 19b, 19c, 19d, 19g, 19l, 19n, } \\
\text { 19p, 19t, 19ab, 19ac, 19ad, } \\
\text { 19ag, 19ai, 19ap, 19ar, 19at, } \\
\text { 19ay, 19az, 19ba, 19bj }\end{array}$ & 20 \\
\hline Thinking & $\begin{array}{l}\text { 19a, 19f, 19k, 19m, 19r, 19u, } \\
\text { 19x, 19aj, 19aq, 19au, 19bc, } \\
\text { 19bg, 19bh, 19bl }\end{array}$ & 14 \\
\hline Common Nucleus & $\begin{array}{l}\text { 19e, 19h, 19j, 19o, 19q, 19aa, } \\
19 \text { ah, 19al, 19ao, 19av, 19aw, } \\
\text { 19be, 19bi, 19bm }\end{array}$ & 14 \\
\hline
\end{tabular}

Implementation of the instrument. Due to the magnitude of the project, a company specialized in carrying out surveys was hired to visit each one of the 413 schools and interview the 754 EMS teachers. The survey given to the company had already been designed and validated, as outlined above. The company's work consisted of 1) digitalizing the instrument so that the teachers could answer on an electronical device (Tablet); and 2) visiting all the schools to apply the survey to the teachers previously selected. To this end, the project leader arranged the required official permits and gave the company a list with the names of the teachers to be interviewed, the names and addresses of the schools where they worked, and the schedules available to visit them, among other relevant information. Once the surveys were administered, the company 3 ) returned the database with all the teachers' responses to the project leader in SPSS database.

Method of data analysis. Data analysis was based on a sampling process using Exploratory Factorial Analysis, which began by including the responses of all 754 teachers to the 65 items on the instrument. These 65 items presented a maximum of $2.7 \%$ of null values (i.e., no answer). On each item, all 7 answer options (1. Never; 2. Almost never; 3. Just below what is indispensable; 4. Just what is indispensable; 5. A little more than what is indispensable; 6. Much more than what is indispensable; and 7. I give it the greatest emphasis) were marked at least once. The highest accumulation for one option was $37.9 \%$. This was usually option 6. Much more than indispensable, which thus showed a ceiling effect. In other words, interviewees' answers focused on the 4 options with the highest values: 4. Just what is indispensable; 5. A little more than what is indispensable; 6. Much more than what is indispensable; and 7. I give it the greatest emphasis. These scores lead to the conclusions that the results consisted, empirically, of 7 points, and that the items efficiently collected the variability present in the sample $(N=754)$.

Exploratory Factorial Analysis was performed with SPSS software (version 25). The extraction method was Maximum Likelihood. Through this process 28 items were discarded from the total of 65 . The following results focused on the responses to the remaining 37 items.

\section{RESULTS}

The unidimensional model obtained from those 37 items explained $60.42 \%$ of total variance and presented a Kaiser-Meyer-Olkin adequation sample of $0.991(p<0.001)$. The scale elaborated with the sum of the scores from the 37 items presented an alpha reliability rate $=0.982$, a range of 16-252 points, 
a median of 193 points, and first and third quartiles of 166 and 216.25 points, respectively. The 37 items were distributed as follows: nine for SL, eight for SR, 11 for ST, and nine for CN (see Tables 4, 5, 6, \& 7). When compared to the 65 items, the unidimensional model of the 37 items maintained $52 \%, 40 \%$, $78 \%$ and $64 \%$ of the SL, SR, ST, and CN items respectively.

\subsection{EMPIRICAL MODEL OF THE SL, SR AND ST APPROACHES}

The unidimensional model had already been observed in the pilot study, but it reappeared during the final study. Although the questionnaire was designed with a tridimensional model with common elements in mind, as some authors indicate (see Figure 4a), the Exploratory Factorial Analysis revealed that the resulting unidimensional model shows that the teachers did not vary their inclinations towards any one of the three approaches to statistical teaching (SL, SR and ST). In other words, empiricallyspeaking, only one dimension, which included elements of each approach in a balanced manner, was presented (see Figure 4b).

Theoretical Model

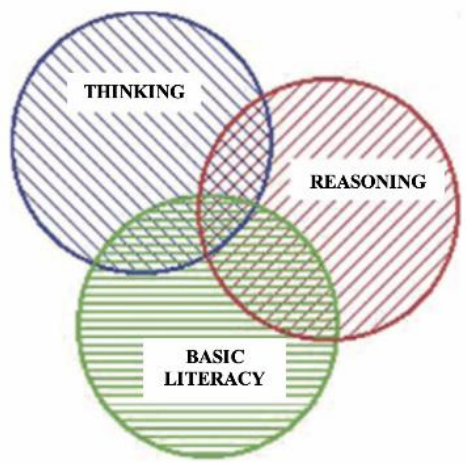

(a)
Empirical Model

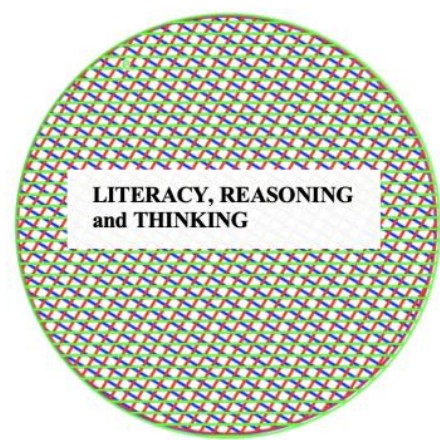

(b)

Figure 4. Theoretical and empirical models of the approaches to statistics teaching

The empirical model indicates that, in the perspective of our interviewees, elements from all three approaches are taught, with no reliance on over the others. This could mean that the 37 items represented in the Empirical Model measures elements that are inside the zone where the three approaches overlap (Figure 4a, Theoretical Model).

\subsection{SCORE FREQUENCIES OF THE ITEMS IN THE EMPIRICAL MODEL}

Statistical literacy. According to the teachers' responses to the nine SL items, the elements of this approach that they encouraged are related to four of the five elements of knowledge that Gal (2002) suggested: Statistical literacy skills, Basic statistical knowledge, Contextual knowledge and Critical questions (see Table 4). The items that measured the elements of basic statistical knowledge appeared with the highest frequency (4/9), followed by critical questions (3/9) and, though at a low frequency, contextual knowledge, and statistical literacy skills (1/9 each). According to these frequencies, it seems that most of these EMS teachers focused on teaching aspects they considered "Much more than what is indispensable."

The statistical content demanded by questions 19s, 19y, 19ae, 19bk and 19ak is related to that suggested in the MCC (see Table 1): "Information management in everyday situations" (19y and 19ae); "Managing central tendency measures" (19bk and 19ak); and "Managing and understanding dispersion measures" (19s). In contrast, the statistical content demanded by questions 19w, 19af, 19as and 19bd does not seem to address any of the central content suggested in the MCC. Questions 19w and 19bd involved ideas related to samples, while the content of questions 19af and 19as is related to the nature of the data. Since the MCC demands the minimum disciplinary skills that EMS systems must address, these results show that EMS teachers exceeded those disciplinary skills for the study of statistics. 
Table 4. Frequency of the SL items scores.

\begin{tabular}{|c|c|c|c|c|c|c|c|c|}
\hline \multirow[t]{2}{*}{ Question } & \multirow[t]{2}{*}{ Element } & \multicolumn{7}{|c|}{ Frequency of responses } \\
\hline & & 1 & 2 & 3 & 4 & 5 & 6 & 7 \\
\hline $\begin{array}{l}\text { 19s. To what extent do you teach your } \\
\text { students that atypical observations can lead to } \\
\text { an incorrect interpretation of statistical } \\
\text { results? }\end{array}$ & $\begin{array}{l}1.1 .4 \\
\text { Critical } \\
\text { questions }\end{array}$ & 10 & 34 & 53 & 143 & 190 & 210 & 107 \\
\hline $\begin{array}{l}19 \mathrm{w} \text {. To what extent do you teach your } \\
\text { students to understand the different ways to } \\
\text { select samples? }\end{array}$ & $\begin{array}{l}1.1 .2 \text { Basic } \\
\text { statistical } \\
\text { knowledge }\end{array}$ & 7 & 29 & 31 & 117 & 188 & 240 & 140 \\
\hline $\begin{array}{l}19 y \text {. To what extent do you teach your } \\
\text { students to see relations (or general patterns) } \\
\text { among the data in a graph instead of only } \\
\text { specific points? }\end{array}$ & $\begin{array}{l}1.1 .2 \text { Basic } \\
\text { statistical } \\
\text { knowledge }\end{array}$ & 6 & 14 & 37 & 106 & 197 & 252 & 138 \\
\hline $\begin{array}{l}\text { 19ae. To what extent do you teach your } \\
\text { students to recognize that the same statistical } \\
\text { information can be observed in different } \\
\text { forms of registration (e.g., tables, graphs, } \\
\text { numbers)? }\end{array}$ & $\begin{array}{l}1.1 .1 \\
\text { Literacy } \\
\text { skills }\end{array}$ & 3 & 9 & 22 & 69 & 204 & 266 & 180 \\
\hline $\begin{array}{l}\text { 19af. To what extent do you teach your } \\
\text { students to comprehend the importance of } \\
\text { considering the origin of the data to reach a } \\
\text { correct interpretation? }\end{array}$ & $\begin{array}{l}1.1 .3 \\
\text { Context } \\
\text { knowledge }\end{array}$ & 4 & 15 & 38 & 83 & 178 & 234 & 201 \\
\hline $\begin{array}{l}\text { 19ak. To what extent do you teach that } \\
\text { central tendency measures are useful for } \\
\text { comparing groups of data? }\end{array}$ & $\begin{array}{l}\text { 1.1.2 Basic } \\
\text { statistical } \\
\text { knowledge }\end{array}$ & 4 & 8 & 30 & 92 & 179 & 265 & 170 \\
\hline $\begin{array}{l}\text { 19as. To what extent do you teach how the } \\
\text { data that appear in different media are } \\
\text { produced (e.g., experiments, surveys, } \\
\text { censuses)? }\end{array}$ & $\begin{array}{l}\text { 1.1.2 Basic } \\
\text { statistical } \\
\text { knowledge }\end{array}$ & 5 & 21 & 40 & 100 & 178 & 231 & 177 \\
\hline $\begin{array}{l}\text { 19bd. To what extent do you teach your } \\
\text { students to question whether the sample in a } \\
\text { message or statistical study leads to a valid } \\
\text { inference about the study population? }\end{array}$ & $\begin{array}{l}1.1 .4 \\
\text { Critical } \\
\text { questions }\end{array}$ & 9 & 33 & 51 & 132 & 201 & 205 & 120 \\
\hline $\begin{array}{l}\text { 19bk. To what extent do you set situations for } \\
\text { your students to reflect on which central } \\
\text { tendency measure is most appropriate } \\
\text { according to the characteristics of the data? }\end{array}$ & $\begin{array}{l}1.1 .4 \\
\text { Critical } \\
\text { questions }\end{array}$ & 9 & 18 & 38 & 121 & 181 & 243 & 140 \\
\hline
\end{tabular}

1. Never; 2. Almost never; 3. Just below what is indispensable; 4. Just what is indispensable; 5. A little more than what is indispensable; 6 . Much more than what is indispensable; and 7. I give it the greatest emphasis.

Statistical reasoning. Of the eight SR items, five corresponded specifically to reasoning on central statistical ideas like data (1/8), distribution (3/8), and sampling (1/8) (see Table 5). The other three items were distributed between the capacity to explain processes and interpret statistical results $(2 / 8)$, the use of statistical evaluations, and monitoring of statistical learning (1/8). These eight items represented the four principle theoretical ideas from which the indicators of SR were designed (see Figure 3). 
Table 5. Frequency of the SR items scores

\begin{tabular}{|c|c|c|c|c|c|c|c|c|}
\hline \multirow[t]{2}{*}{ Question } & \multirow[t]{2}{*}{ Element } & \multicolumn{7}{|c|}{ Frequency of responses } \\
\hline & & 1 & 2 & 3 & 4 & 5 & 6 & 7 \\
\hline $\begin{array}{l}\text { 19b. To what extent do you ask your } \\
\text { students to explain the choice of a certain } \\
\text { statistical procedure? }\end{array}$ & $\begin{array}{l}2.2 \text { Capacity to explain } \\
\text { processes and interpret } \\
\text { statistical results }\end{array}$ & 13 & 40 & 43 & 132 & 204 & 204 & 115 \\
\hline $\begin{array}{l}19 \mathrm{~g} \text {. To what extent do you teach your } \\
\text { students to explore the graphical } \\
\text { representation of the data in relation to its } \\
\text { dispersion (range, interquartile range, } \\
\text { atypical data, standard deviation)? }\end{array}$ & $\begin{array}{l}\text { 2.1.2 Reasoning on } \\
\text { distribution }\end{array}$ & 9 & 23 & 40 & 125 & 185 & 240 & 123 \\
\hline $\begin{array}{l}19 \mathrm{p} \text {. To what extent do you teach your } \\
\text { students to explore the graphical } \\
\text { representation of a set of data according to } \\
\text { its shape (e.g., to visualize slants or } \\
\text { symmetry)? }\end{array}$ & $\begin{array}{l}\text { 2.1.2 Reasoning on } \\
\text { distribution }\end{array}$ & 11 & 36 & 52 & 146 & 180 & 196 & 126 \\
\hline $\begin{array}{l}\text { 19ag. To what extent do you teach your } \\
\text { students to examine the variation present in }\end{array}$ & $\begin{array}{l}2.1 .3 \text { Reasoning on } \\
\text { variability }\end{array}$ & 13 & 38 & 56 & 141 & 195 & 213 & 95 \\
\hline a sample, or between samples? & $\begin{array}{l}\text { 2.1.8 Reasoning on } \\
\text { sampling }\end{array}$ & & & & & & & \\
\hline $\begin{array}{l}\text { 19ai. To what extent do you teach your } \\
\text { students to explore the graphical distribution } \\
\text { of a set of data according to central tendency } \\
\text { and dispersion measures? }\end{array}$ & $\begin{array}{l}\text { 2.1.2 Reasoning on } \\
\text { distribution }\end{array}$ & 5 & 15 & 22 & 113 & 182 & 239 & 145 \\
\hline $\begin{array}{l}\text { 19ap. To what extent do you teach your } \\
\text { students to examine or explore a set of data } \\
\text { as a whole (as a distribution), instead of } \\
\text { seeing them as separate data? }\end{array}$ & $\begin{array}{l}\text { 2.1.1 Reasoning on } \\
\text { data }\end{array}$ & 10 & 15 & 45 & 110 & 190 & 228 & 151 \\
\hline $\begin{array}{l}\text { 19ar. To what extent do you ask your } \\
\text { students to explain their reasoning to justify } \\
\text { a statistical conclusion? }\end{array}$ & $\begin{array}{l}2.2 \text { Capacity to explain } \\
\text { processes and interpret } \\
\text { statistical results }\end{array}$ & 5 & 14 & 33 & 102 & 185 & 241 & 171 \\
\hline $\begin{array}{l}19 \mathrm{ba} \text {. To what extent do you teach your } \\
\text { students to provide proofs and arguments } \\
\text { that support their answers to a statistical } \\
\text { problem? }\end{array}$ & $\begin{array}{l}2.4 \text { Use of evaluations } \\
\text { and monitoring of } \\
\text { statistics learning }\end{array}$ & 8 & 30 & 43 & 115 & 201 & 217 & 137 \\
\hline
\end{tabular}

The findings from the nine SL items showed that EMS teachers seemed to address more statistical content (specially that related to ideas about sample and data) than the minimum suggested in the MCC. The results of the SR items provided evidence for these findings. On the one hand, question 19ag also relates to sampling ideas, while question 19ap relates to data, which means that the teachers' responses were consistent with what they claimed to be teaching. On the other hand, teachers seemed to deepen that content in a more conceptual way than the expected learning stated in the MCC; for instance, questions 19g, 19p and 19ai conveyed a deeper understanding of what was involved in the expected learning for: "Information management in everyday situations", "Managing central tendency measures", and "Managing and understanding dispersion measures" (see Table 1). Questions 19b, 19ar and 19ba, meanwhile, exemplify what EMS teachers appeared to be doing to promote such conceptual understanding: explain the choice of a certain statistical procedure, justify a statistical conclusion, and provide proofs and arguments that support their answers to a statistical problem.

Statistical thinking. With the exception of the data phase, the teachers stated that they promoted elements of the PPDAC investigative cycle in their lessons; in fact, there were more items from the problem phase (4/11) than from the planning (1/11), analysis (1/11), or conclusion (1/11) phases (see Table 6). Regarding the basic types of statistical thinking, teachers stated that they teach aspects related to transnumeration (1/11), variation (2/11) and reasoning with models (1/11). 
Table 6. Frequency of the ST items scores.

\begin{tabular}{|c|c|c|c|c|c|c|c|c|}
\hline \multirow{2}{*}{ Question } & \multirow{2}{*}{ Element } & \multicolumn{7}{|c|}{ Frequency of responses } \\
\hline & & 1 & 2 & 3 & 4 & 5 & 6 & 7 \\
\hline $\begin{array}{l}\text { 19a. To what extent do you teach your students to } \\
\text { finish a statistical analysis by interpreting the } \\
\text { statistical results according to the knowledge } \\
\text { obtained about the situation from which the data } \\
\text { came? }\end{array}$ & 3.1.5 Conclusions & 3 & 23 & 37 & 134 & 174 & 229 & 151 \\
\hline $\begin{array}{l}\text { 19f. To what extent do you teach your students to } \\
\text { explore (or ascertain) the context from which the } \\
\text { statistical problem arose? }\end{array}$ & 3.1.1 Problem & 9 & 22 & 45 & 123 & 194 & 219 & 140 \\
\hline $\begin{array}{l}\text { 19k. To what extent do you set situations where } \\
\text { your students decide when and how to use } \\
\text { statistical methods appropriately (e.g., graphs, } \\
\text { central tendency measures, dispersion measures, } \\
\text { reliability intervals, P value, regression methods, or } \\
\text { time-series models) for data analysis? }\end{array}$ & $\begin{array}{l}\text { 3.2.4 Reasoning } \\
\text { with statistical } \\
\text { models }\end{array}$ & 12 & 24 & 47 & 131 & 189 & 203 & 143 \\
\hline $\begin{array}{l}\text { 19r. To what extent do you teach variation (e.g., } \\
\text { variance) in relation to predicting, explaining or } \\
\text { controlling? }\end{array}$ & 3.2.3 Variation & 14 & 28 & 49 & 153 & 195 & 200 & 112 \\
\hline $\begin{array}{l}\text { 19u. To what extent do you teach your students to } \\
\text { anticipate the design required to solve a statistical } \\
\text { problem (e.g., thinking about what needs to be } \\
\text { measured and how to measure it)? }\end{array}$ & 3.1.2 Plan & 14 & 27 & 48 & 125 & 199 & 211 & 123 \\
\hline $\begin{array}{l}\text { 19x. To what extent do you propose situations in } \\
\text { which your students evaluate their own statistical } \\
\text { results or those of others? }\end{array}$ & 3.1.4 Analysis & 6 & 30 & 47 & 117 & 185 & 235 & 131 \\
\hline $\begin{array}{l}\text { 19aj. To what extent do you teach that, in the case } \\
\text { of a real-world problem, statistical investigation on } \\
\text { the problem will provide part of the understanding } \\
\text { necessary to reach a solution? }\end{array}$ & 3.1.1 Problem & 4 & 16 & 43 & 78 & 184 & 236 & 189 \\
\hline $\begin{array}{l}\text { 19aq. To what extent do you teach that to solve or } \\
\text { judge a real-world problem using statistics, it is } \\
\text { necessary to ask questions that must be answered } \\
\text { by compiling, analyzing and interpreting data? }\end{array}$ & 3.1.1 Problem & 3 & 13 & 42 & 97 & 176 & 239 & 183 \\
\hline $\begin{array}{l}\text { 19bg. To what extent do you teach your students to } \\
\text { transform or express data in different formats to } \\
\text { reveal new characteristics? }\end{array}$ & $\begin{array}{l}3.2 .2 \\
\text { Transnumeration }\end{array}$ & 12 & 28 & 44 & 146 & 208 & 215 & 96 \\
\hline $\begin{array}{l}\text { 19bh. To what extent do you teach your students to } \\
\text { interpret statistical results in terms of variability } \\
\text { (e.g., the results of an electoral survey must be } \\
\text { interpreted as estimates that may vary from one } \\
\text { sample to the next)? }\end{array}$ & 3.2.3 Variation & 12 & 25 & 50 & 123 & 193 & 225 & 123 \\
\hline $\begin{array}{l}\text { 19bl. To what extent do you encourage your } \\
\text { students to create problems that can be solved with } \\
\text { statistics? }\end{array}$ & 3.1.1 Problem & 5 & 18 & 37 & 111 & 176 & 245 & 160 \\
\hline
\end{tabular}

Continuing with what we noticed in the SL and SR results, the ST questions support the extra content that EMS teachers seemed to teach, and the deeper understanding they promoted in their statistics teaching. Questions 19f, 19aj, 19aq and 19bl provided evidence that EMS teachers keep statistical investigations in mind to solve real-world problems, anticipate the data required to solve them (question 19u), and consider the contextual knowledge of the problem when interpreting the statistical results (question 19a). Like question 19b of the SR items, question 19k of ST items revealed that EMS 
teachers motivated their students' statistical reasoning, especially in relation to deciding and explaining the use of statistical procedures and models for data analysis, and justifying a statistical conclusion (question 19ar of the SR items).

Items $19 \mathrm{bh}$ and 19r provide a clearer vision of how teachers may have conveyed to their class the central content of "Managing and understanding dispersion measures", and item 19bg, "Information management in everyday situations".

Common Nucleus. Here, nine of the $14 \mathrm{CN}$ items stayed inside the unidimensional model. These nine items (see Table 7) measured aspects related to elements of all three approaches (SL, SR, ST). However, the fact that we obtained, empirically, a unidimensional model, indicates that these EMS teachers stated that these common elements were taught at the same level as the SL, SR and ST elements.

Table 7. Frequency of the CN items scores.

\begin{tabular}{|c|c|c|c|c|c|c|c|}
\hline \multirow{2}{*}{ Question } & \multicolumn{7}{|c|}{ Frequency of responses } \\
\hline & 1 & 2 & 3 & 4 & 5 & 6 & 7 \\
\hline $\begin{array}{l}\text { 19h. To what extent do you teach your students to identify factors that } \\
\text { cause variation? }\end{array}$ & 13 & 29 & 60 & 131 & 220 & 201 & 96 \\
\hline $\begin{array}{l}\text { 19o. To what extent do you teach your students to question whether a } \\
\text { statistical message, study or summary has a sufficiently large sample? }\end{array}$ & 13 & 25 & 58 & 134 & 193 & 207 & 121 \\
\hline $\begin{array}{l}\text { 19q. To what extent do you teach your students to represent the data in } \\
\text { different ways to reveal patterns? }\end{array}$ & 9 & 27 & 51 & 133 & 195 & 210 & 127 \\
\hline $\begin{array}{l}\text { 19aa. To what extent do you teach your students to recognize the } \\
\text { existence of variations? }\end{array}$ & 6 & 23 & 41 & 132 & 214 & 228 & 104 \\
\hline $\begin{array}{l}\text { 19al. To what extent do you ask your students to present statistical } \\
\text { data to prove their assumptions? }\end{array}$ & 10 & 31 & 46 & 150 & 168 & 200 & 146 \\
\hline $\begin{array}{l}\text { 19ao. While using statistical information, to what extent do you teach } \\
\text { your students to question how the data analysis was carried out? }\end{array}$ & 5 & 22 & 42 & 98 & 197 & 253 & 134 \\
\hline $\begin{array}{l}\text { 19av. To what extent do you teach your students to present the data in } \\
\text { different ways to transmit an idea? }\end{array}$ & 5 & 11 & 31 & 103 & 178 & 259 & 166 \\
\hline $\begin{array}{l}19 \mathrm{aw} . \text { While using statistical information, to what extent do you teach } \\
\text { your students to question how they reached their conclusion? }\end{array}$ & 4 & 13 & 35 & 95 & 211 & 220 & 172 \\
\hline $\begin{array}{l}\text { 19bi. To what extent do you add the use of technological tools that } \\
\text { allow your students to realize procedures of statistical calculations? }\end{array}$ & 11 & 40 & 66 & 143 & 194 & 185 & 113 \\
\hline
\end{tabular}

At this point, we can see that some items have similar questions between the NC items and those of the SL, SR and ST (see Table 8), and perceive how those questions are associated with the central content suggested in the MCC, and with that extracurricular content.

Table 8. Similarities between the CN items and those of the SL, SR and ST

\begin{tabular}{lllll}
\hline \multicolumn{1}{c}{ Central content of the MCC } & SL items & SR items & ST items & CN items \\
\hline $\begin{array}{l}\text { Information management in everyday situations } \\
\text { Managing central tendency measures }\end{array}$ & $\begin{array}{l}\text { 19y, 19ae, } \\
\text { 19ak, 19bk }\end{array}$ & 19ai & 19k, 19bg & $19 \mathrm{q}, 19 \mathrm{av}$ \\
Managing and understanding dispersion measures & & $19 \mathrm{~g}, 19 \mathrm{ag}, 19 \mathrm{ai}$ & 19r, 19bh & $19 \mathrm{~h}, 19 \mathrm{aa}$ \\
\hline \multicolumn{1}{c}{ Extracurricular content } & & & \\
\hline Ideas about sampling & 19w, 19bd & $19 \mathrm{ag}$ & $19 \mathrm{o}$ \\
Ideas about data & 19af, 19as, & $19 \mathrm{al}$ \\
\hline
\end{tabular}

In summary, EMS teachers taught all three approaches in a balanced manner. As is to be expected, they went deeper than the disciplinary skills stated in the MCC, in terms of both content and 
understanding. Although these results indicate that there were no differences in the teaching approaches to statistics used by these EMS teachers, the difference that can be seen between one teacher and another is one of intensity, according to the Likert-type response scale established: 1. Never; 2. Almost never, 3; Just below what is indispensable; 4. Just what is indispensable; 5. A little more than what is indispensable; 6. Much more than what is indispensable; and 7. I give this the greatest emphasis.

\subsection{DIFFERENCES IN THE TEACHING OF STATISTICS AMONG THE EDUCATIONAL SYSTEMS}

An alternative way of explaining the meaning of the differences among EMS teachers is by analyzing the differences among the educational systems in which they worked $(H=46.713, p<0.001)$ using the Kruskal-Wallis test (see Table 9).

Table 9. Ranges on the Kruskal-Wallis test

\begin{tabular}{lcc}
\hline Educational system & $\begin{array}{c}\text { No. of teachers } \\
\text { interviewed }\end{array}$ & $\begin{array}{c}\text { Average } \\
\text { range }\end{array}$ \\
\hline CONALEP EDOMEX & 60 & 484.28 \\
CONALEP CDMX & 54 & 460.28 \\
UNAM & 26 & 435.71 \\
COLBACH & 40 & 425.35 \\
CECyTEM & 46 & 390.87 \\
UEMSTIS & 102 & 377.01 \\
EPOEM & 277 & 355.46 \\
CBT & 78 & 351.77 \\
IPN & 31 & 330.82 \\
COBAEM & 32 & 253.44 \\
UEMSTAyCM & 4 & 251.50 \\
DGB & 4 & 172.63 \\
\hline \multicolumn{2}{c}{ Total } & 754 \\
\hline
\end{tabular}

Table 9 shows that, according to their responses, EMS teachers who placed greater emphasis on the teaching of statistics - using all three approaches: SL, SR and ST - work at schools pertaining to the following educational systems: CONALEP EDOMEX, CONALEP CDMX, UNAM and COLBACH; while those who taught statistics with lesser emphases work at the COBAEM, UEMSTAyCM and DGB.

It is important to point out, specifically, that the study program the teachers in the COBAEM and DGB educational systems used to teach statistics offered the lowest statistical content and required less teaching time (16 hours: 8 for statistical topics, 8 for probability topics). This is because statistics and probability were taught as part of the teaching contents of a course called Mathematics II at $2^{\text {nd }}$ semester. The other educational systems, in contrast, included the teaching of statistics and probability as subjects separate from mathematics (81 hours approximately) and, generally, offered courses on statistics and probability in the $5^{\text {th }}$ and $6^{\text {th }}$ semesters (that is, the final two semesters of EMS). In the particular case of UNAM schools, the statistics and probability course was offered as an optional course.

Another important observation is that the teachers of the UEMSTAyCM educational system seemed to teach the three approaches with less emphasis even though they worked with the same study program as the UEMSTIS and CECyTEM systems.

\section{CONCLUSIONS AND FINAL THOUGHTS}

This article presents the design and application of a questionnaire designed to ascertain to what extent teachers focus on elements of the three main approaches to statistics teaching; that is, SL, SR and ST. On the one hand, results indicate that there are no differences in the emphasis on teaching one approach above the others. Empirically-speaking, EMS teachers we interviewed taught elements from all three approaches in a balanced way. This suggests that there may be more common elements than 
distinct ones among the three approaches, and this finding is what led us to assess the possibility of combining them into a unidimensional approach.

In addition, our results provided a panorama on the current state of statistics teaching at EMS level in Mexico. The following paragraphs highlight aspects of this panorama according to the information presented herein.

- Statistics teaching at EMS level is recognized as a key element that promotes the development of basic disciplinary skills in the field of mathematics, as the MCC of EMS recommends (SEP, 2017). In the case of the teaching of statistics -a discipline within mathematics- the MCC represents an effort by educational authorities to unify the central contents of statistics (see Table 1) that should be studied in the different educational systems that form EMS in Mexico.

- The central content of the MCC addresses basic aspects of statistics teaching and emphasizes learning and the expected products suggested by a more procedural than conceptual understanding of the content. However, each educational system must delve into, and expand, this content according to its own teaching goals. Results show that teachers teach extra content to that outlined in the MCC.

- Contrary to the unidimensional model that follows from the EMS teachers' responses, the analysis of the content of the study programs (first stage of the Project) showed a difference among SL, SR and ST (Chávez, 2020; Gómez-Blancarte, Chávez, \& Miranda, in press). That is, there are study programs that promote elements of one approach more than another but teachers do not distinguish one approach from another in their teaching. The aforementioned corroborates a difference between the theoretical and practical understanding of these three approaches.

- Although the teachers stated that they teach elements from all three approaches of statistics teaching in a balanced manner, the emphasis in their teaching activity varies according to EMS educational system to which they pertain.

We consider that the importance of the present study resides, on the one hand, in the elaboration of a reliable instrument that makes it possible to explore the elements of the ST, SR and ST approaches that teachers promote. There are tools that measure students' learning of statistics in relation to these approaches, but it is also necessary to ascertain to what extent teachers promote this learning. On the other hand, in identifying that, depending on the teachers' perspectives, in practice there does not seem to be a difference in teaching these approaches.

Although the teachers stated that they taught all three approaches (SL, SR, ST), further research is needed (e.g., interviews and classroom observations) to determine how the elements of these approaches are handled and used by teachers. In this sense, we agree with delMas (2002) that "what moves us from one of the three domains to the other is not so much the contents, rather, it is what we ask the students to do with the contents" (p. 5). For instance, our own educational experience, documentary research and field observations have taught us that teachers, and some educational programs, tend to equate statistical problems with exercises from textbooks, but this does not satisfy the criteria of a statistical problem according to the ST approach. Another example is the use of projects. Teachers often assign a project as the final task in their statistics courses, even though this may not necessarily fulfil the idea of using statistics projects as a way to conduct statistical investigations.

\section{ACKNOWLEDGMENTS}

This project was supported by the Fondo Sectorial de Investigación para la Evaluación de la Educación del Consejo Nacional de Ciencia y Tecnología and the Instituto Nacional para la Evaluación de la Educación (CONACYT-INEE), Project Registration Number: 289262, and with the support of the Instituto Politécnico Nacional, Projects 20180663 and 20195780.

\section{REFERENCES}

American Statistics Association. (2016). Guidelines for Assessment and Instruction in Statistics Education (GAISE) College Report. Author. http://www.amstat.org/asa/education/Guidelines-forAssessment-and-Instruction-in-Statistics-Education-Reports.aspx 
Batanero, C. (2001). Didáctica de la estadística. [Didactics of statistics] Grupo de Investigación en Educación Estadística, Departamento de Didáctica de la Estadística, Universidad de Granada.

Batanero, C., Burrill, G., \& Reading, C. (Eds.). (2011). Teaching statistics in school mathematicschallenges for teaching and teacher education. A joint ICME/IASE study: The 18th ICMI study. Springer.

Ben-Zvi, D., \& Garfield, J. (Eds.). (2004). The challenge of developing statistical literacy, reasoning and thinking. Kluwer Academic Publishers.

Burrill, G., \& Biehler, R. (2011). Fundamental statistical ideas in the school curriculum and in training teachers. In C. Batanero, G. Burrill, \& C. Reading (Eds.), Teaching statistics in school mathematicschallenges for teaching and teacher education. A joint ICME/IASE study: The 18th ICMI study (pp. 57-69). Springer.

Campos, T. M. M., Cazorla, I. M., \& Kataoka, V. Y. (2011). Statistics school curricula in Brazil. In C. Batanero, G. Burrill, \& C. Reading (Eds.), Teaching statistics in school mathematics-challenges for teaching and teacher education. A joint ICME/IASE study: The 18th ICMI study (pp. 5-8). Springer.

Casanova, A. F. (2005). Ensayo histórico del desarrollo de la estadística en México. [Historical essay on the development of statistics in Mexico] El Portulano de la Ciencia, 2(13), 451-498.

Chance, B. L. (2002). Components of statistical thinking and implications for instruction and assessment. Journal of Statistics Education, 10(3). https://doi.org/10.1080/10691898.2002.11910677

Chávez, A. R. D. (2020). Características de la enseñanza de la estadística en los programas de estudio de educación media superior. [Characteristics of the teaching of statistics in high school curriculum] [Unpublished Master's Thesis, Instituto Politécnico Nacional, Ciudad de México]

delMas, R. C. (2004). A comparison of mathematical and statistical reasoning. In D. Ben-Zvi \& J. Garfield (Eds.), The challenge of developing statistical literacy, reasoning, and thinking (pp. 7995). Kluwer Academic Publishers.

delMas, R. (2002). Statistical literacy, reasoning, and learning: A commentary. Journal of Statistics Education, 10(3), 1-9. https://doi.org/10.1080/10691898.2002.11910679

Franklin, C., Kader, G., Mewborn, D., Moreno, J., Peck, R., Perry, M., \& Scheaffer, R. (2005). Guidelines for Assessment and Instruction in Statistics Education (GAISE) Report. American Statistical Association. http://www.amstat.org/asa/education/Guidelines-for-Assessment-andInstruction-in-Statistics-Education-Reports.aspx

Gal, I. (2004). Statistical literacy. Meanings, components, responsibilities. In D. Ben-Zvi \& J. Garfield, (Eds.), The challenge of developing statistical literacy, reasoning and thinking (pp. 47-78). Kluwer Academic Publishers.

Gal, I. (2002). Adult's statistical literacy. Meanings, components, responsibilities. International Statistical Review, 70(1), 1-25. https://doi.org/10.1111/j.1751-5823.2002.tb00336.x

Garfield, J. (2011). Statistical literacy, reasoning, and thinking. In M. Lovric (Ed.), International Encyclopedia of Statistical Science (pp. 1439-1442). Springer. https://doi.org/10.1007/978-3-64204898-2

Garfield, J. (2002). The challenge of developing statistical reasoning. Journal of Statistics Education, 10(3). https://doi.org/10.1080/10691898.2002.11910676

Garfield, J., \& Ben-Zvi, D. (2008). Developing students' statistical reasoning. Connecting research and teaching practice. Springer.

Garfield, J., \& Franklin, C. (2011). Assessment of learning, for learning, and as learning in statistics education. In C. Batanero, G. Burrill, \& C. Reading (Eds.), Teaching statistics in school mathematics: Challenges for teaching and teacher education. A joint ICME/IASE study: The 18th ICMI study (pp. 133-145). Springer.

Gómez-Blancarte, A. L. (2015). Aprendizaje de profesores en servicio para la enseñanza de la estadística. Un analysis a partir del proceso de Negociación de Significados. [In-service teacher learning for teaching statistics. An analysis based on the process of Negotiation of Meaning] Publicia.

Gómez-Blancarte, A. L., Chávez A. R. D., \& Miranda, V. I. (in press). Enfoques de la enseñanza de la estadística en los programas de estudio de educación media superior. [Approaches to teaching statistics in the high school programs of study] IE Revista De Investigación Educativa De La REDIECH. 
Gómez-Blancarte, A., \& Santana, O. A. (2018). Research on statistical projects: looking for the development of statistical literacy, reasoning, and thinking. In M. A. Sorto, A. White, \& L. Guyot (Eds.), Looking Back, Looking Forward. Proceedings of the Tenth International Conference on Teaching Statistics (ICOTS-10), Kyoto, Japan. https://iase-web.org/icots/10/proceedings/pdfs/ICOTS10_1E3.pdf

Newton, J., Dietiker, L., \& Horvath, A. (2011). Statistics education in the United States: statistical reasoning and the statistical process. In C. Batanero, G. Burrill, \& C. Reading (Eds.), Teaching statistics in school mathematics: Challenges for teaching and teacher education. A joint ICME/IASE study: The 18th ICMI study (pp. 9-13). Springer.

Opolot-Okurut, C., \& Eluk, P. O. (2011). Statistics school curricula for Uganda. In C. Batanero, G. Burrill, \& C. Reading (Eds.), Teaching statistics in school mathematics: Challenges for teaching and teacher education. A joint ICME/IASE study: The 18th ICMI study (pp. 15-19). Springer.

Sánchez, E. (2009). La probabilidad en el programa de estudio de matemáticas de la secundaria en México. [The probability in the secondary school math curriculum in Mexico] Educación Matemática, 21(2), 39-77.

Secretaría de Educación Pública. (2011). Programas de Estudio 2011. Guía para el Maestro. Educación Básica. Secundaria. Matemáticas. [Study Programs 2011, Guide to the Teacher. Basic Education. Secondary. Mathematics] Author.

Secretaría de Educación Pública. (2017). Planes de Estudio de Referencia del Marco Curricular Común de la Educación Media Superior. [Reference study plans of the common curriculum framework for higher middle education]. Author.

Wessels, H. (2011). Statistics in the South Africa school curriculum. In C. Batanero, G. Burrill, \& C. Reading (Eds.), Teaching statistics in school mathematics-challenges for teaching and teacher education. A joint ICME/IASE study: The 18th ICMI study (pp. 21-25). Springer.

Wild, C., \& Pfannkuch, M. (1999). Statistical thinking in empirical enquiry (with discussion). International Statistical Review, 67(3), 223-265. https://doi.org/10.2307/1403700

Ziegler, L. A. (2014). Reconceptualizing statistical literacy: Developing an assessment for the modern introductory statistics course. [Doctoral dissertation, University of Minnesota] https://hdl.handle.net/11299/165153

Ana Luisa Gómez-Blancarte Instituto Politécnico Nacional, CICATA-Legaria Calzada Legaria no. 694, col. Irrigación C.P. 11500, Alcaldía Miguel Hidalgo Ciudad de México, México 